\title{
DEVELOPMENTS IN JURISDICTION OVER NONRESIDENT' INDIVIDUALS DOING LOCAL BUSINESS
}

\section{By Sermour G. Clark, Jr.*}

\begin{abstract}
"No sovereignty can extend its process beyond its own territorial limits to subject either persons or property to its judicial decisions. Every exertion of authority of this sort beyond this limit is a mere nullity, and incapable of binding such a person or property in any other tribunal."1
\end{abstract}

The above quotation not only expresses the orthodox view of American jurisprudence relating to the Conflict of Laws but also reflects the traditional view with reference to the requirements of due process imposed by the constitution or the courts of the overreaching state. ${ }^{2}$ Nevertheless, on various theories, judgments against a foreign corporation doing business locally, with or without formal admission to do local business, were recognized as valid under statutes providing for service on the local agent of such corporation. With regard to such corporation, one theory is that the foreign corporation, which could be excluded by a state from doing local intrastate business, by coming into the state to do such business "impliedly consented" to such jurisdiction, at least as to canses of action arising out of the conduct of the local business. ${ }^{3}$ Another theory is the "presence" theory, based on the reasoning that a corporation is present wherever it is doing business; $;$ a theory made possible by the "incorporeal" nature of such a juristic person. The voluntary act of a foreign corporation seeking authority to do local business and, as one step in obtaining sueh authority, expressly consenting to the appointment of an agent to receive process, perhaps hardly deserves to be classified as an additional theory, even though jurisdiction so obtained can extend to out-of-state causes of action. $^{5}$ These rationalizations were specifically restricted to the

* 2d year law student, Duke University; A.B. Duke University, 1951.

1 Story, Comarentaries on the Conflict of Tuaws, $\$ 539$ (6th ed. 1865).

2 Coolex, Consmitumonal Limitamons, pp. 496, 499 (6th ed. 1890).

${ }^{3}$ LaFayette Ins. Co. v. French, 18 How. (U. S.) 404, 15 L. Td. 451 (1855).

- St. Clair v. Cox, 106 U. S. 350 (1882); Goldy v. Morning News, 156 U. S. 518 (1895); Riverside and Dan River Cotton Mills v. Meneffe, 237 U. S. 189 (1915); International Harvester Co. v. Kentucky, 234 U. S. 579 (1914).

Smolik v. Philadelphia \& Reading Coal and Iron Co., 222 Fed. 148 (S. D. N. Y. 1915). For more complete discussions of the three theories see: Scott, Jurisdiction over Non-Residents Doing Business Within a State, 32 HARv. L. REv. 871 (1919), at 880. 
corporate business unit in Flexner $\nabla$. Farson, $^{6}$ or, by later decision, at least to businesses quasi-corporate in form. ${ }^{7}$ Since the state did not have the power to exclude the nonresident individual, reasoned the court in the Flexner case, the analogy to the implied consent theory failed; accordingly, service on the local agent of the nonresident partners was not binding on the partner who had not been personally served. Appearance or personal service was said to be required by the due process clause. ${ }^{8}$ Subsequent decisions in several state courts follow the general doctrine of that case $;^{9}$ nevertheless, an occasional state court strains to justify the actual decision in the Flexner case on the rather dubious idea that the person who was served was not the agent of the defendants at the time of service. ${ }^{10}$

The first inroads upon the doctrine of Flexner v. Farsom came in those cases which, however the court may have rationalized the result, can be categorized as cases where the state had a "high social interest" in the protection of its citizens from the dangers to which they were confronted by the nonresident individual's activities within the state. The three main activities of this class were: (1) driving an automobile on the state's highways; (2) selling securities within the state; (3) conducting operations within the state which were "fraught with danger." State statutes providing for substituted service (i.e., on some state official, usually the Commissioner of Motor Vehicles) on the nonresident motorists were accordingly upheld on the basis of the police power of the state to regulate public safety on the highways, ${ }^{11}$ bolstered by the argument, familiar in the case of the foreign corporation, that the state could exclude the noncitizen from using the highways. ${ }^{12}$ In regard to the sale of securities the Supreme Court in Henry Doherty \& Co. v. Goodman ${ }^{13}$

- 248 U. S. 289 (1918).

"See Hemphill v. Orloff, 277 U. S. 537 (1928).

${ }^{8}$ U. S. Const. ALIEND. XIV, $\$ 1$.

- Andrews Bros. v. MeClanahan, 220 Ky. 504, 295 S. W. 457 (1927); Woodfin v. Curry, 228 Ala. 436, 153 So. 620 (1934); Martin v. Slagle, 178 Tenn. 121, 156 S. W. $2 d 403$ (1941).

${ }^{10}$ Stoner v. Higginson, $316 \mathrm{~Pa} .481,175$ Atl. 527 (1934) ; Miller v. Swann, 176 Misc. 607,28 N. Y. S. $2 d 247$ (1941).

${ }^{11}$ Indeed, this doctrine even antedated the Flexner case. Kane v. New Jersey, 242 U. S. 160 (1916); Hess v. Pawloski, 274 U. S. 352, 352 (1927): " $[I] \mathrm{n}$ the pnblic interest the state may make and enforce regulations reasonably calculated to promote care on the part of all, residents and nonresidents alike."

${ }^{12}$ Kane v. New Jersey, 242 U. S. 160 (1916).

${ }^{13} 294$ U. S. 623 (1935). 
reasoned that since the state had treated such activity as "exceptional" and subject to special regulation, as shown by enactment of a Blue Sky law, the service on the agent of the nonresident was valid, even though made under a general statute relating to "doing business" on the part of nonresidents. The third exception, which can encompass more varied activities, is justified on the ground that the conduct of a "hazardous" business is subject to the "police power" of the state to enact laws for the reasonable protection of its citizens. Accordingly, it was held that the building of a levee was "fraught with danger" and as such the state had the power to provide for substituted service in a local suit against the nonresident contractor. ${ }^{14}$

Prior to the International Shoe case, ${ }^{15}$ which affords a new means to uphold substituted service in local suits against nonresidents engaged in business within the state, there were only two jurisdictions willing to break away from the Flexner decision and say that simply to be conducting "business" (to be contrasted with the specific activities seen above), would be sufficient to make the nonresident amenable to suit by service on his agent. In finding a New York statute ${ }^{16}$ constitutional, the New York court viewed as sufficient the test "whether the cause of action arises out of the conduct of business by the nonresident," $" 17$ and service on the managing agent of the nonresident owners of income-producing buildings was held binding on them in a suit by a plaintiff injured by a fire in the building. The same New York statute was upheld in a later case, ${ }^{18}$ although it was found that the service was invalid, because made in a suit upon a cause of action not arising out of the conduct of local business. Pointing both to the reasonableness of the statute, and for good measure, to the police power concept as embracing "regulations designated to promote public convenience or the prosperity or welfare," the Supreme Court of Pennsyl-

14 Sugg v. Hendrix, 142 F. 2d 740 (5th Cir. 1944).

15 International Shoe Co. v. Washington, 326 U. S. 310 (1945).

${ }^{10}$ N. Y. Civil Practice ACT, $\$ 229$ (b).

${ }_{17}$ Miller v. Swann, 176 Misc. 607,28 N. Y. S. $2 d 247$ (1941); contra: Smith v. Cook, 43 Pa. D. \& C. 608 (1941), as to the collection of rents as amounting to doing business. See also, Dubin v. Philadelphia, 34 Pa. D. \& C. 61 (1938), 87 U. of PA. L. REv. 119 (1938).

${ }_{18}$ Interchemical Corp. v. Mirabelli, 269 App. Div. 224, 54 N. Y. S. 2d 522 (1945). This and the prior New York cases relied on an exhaustive treatment of the entire problem in: Report of the N. Y. Law Rev. Com. Leg. Doc. No. 65 (1940). 
vania $^{10}$ upheld substituted service under a Pennsylvania statute ${ }^{20}$ permitting local suits against a nonresident "who engages in business" in that state. The utilization of this idea has been supported on the basis that, since the nonresident accepts the benefit of the protection of the laws of the state through his agent, he should be amenable to the jurisdiction of the forum, at least within a restricted range of actions. ${ }^{21}$

Although most of the jurisdictions had not so flatly disregarded the reasoning of Flexner v. Frarson, it is interesting to note that a number of state legislatures either enacted statutes providing for substituted service of process on the nonresident individuals subsequently to that decision or simply left prior similar statutes unrepealed. The status of the rule that jurisdiction over individuals rests on physical power must have been uncertain at best in the minds of the legislators of these fourteen states. ${ }^{22}$

In 1945, Mr. Justice Stone speaking for the court in the International Shoe case critically re-examined the fictional approaches upon which the validity for the substituted service statutes rested and formulated a new approach:

"Now that capias ad respondenum has given way to personal service of summons or other form of notice, due process requires only that, in order to subject a defendant to a judgment personam, if he be not present within the forum, he have certain minimum contacts with it such that maintenance of the suit does not offend "traditional notions of fair play and substantial justice." ",23

Given, then, a sufficiency of "minimum contacts" by the nonresident with the state, this "substantial justice" theory considers it "fair play" to render the nonresident amenable to local suit

20 Stoner v. Higginson, 216 Pa. 481, 175 Atl. 527 (1934).

20 PURDoN's PA. STAT. ANN. 1953, Tit. 12, \$ 297.

${ }^{2}$ Daum, Transaction of Business Within the State by a Non-Resident as a Foundation for Jurisdiction, 19 IOWA L. REv. 421 (1934); Culp, Process in Actions Against Non-Residents Doing Business Within a State, 32 Mror. I. REV. 909 (1934).

22 ALA. CODE 1951 Tit. 7, $\$ 199$ (1) ; Der. Rev. CODE 1935, $\$ 4579$; BuRNS' IND. ANN. STAT. 1933, \$2-703; IOWA CODE ANN. 1951, \$56 (g); CARROLII'S KY. Codes 1944, \$51.6; ME. Rev. Stat. 1944, e. $99 \$ 21$; Mrss. Code 1942, $\$ 1437$; N. Y. CIVIL Practice ACT, $\$ 229$ (b) ; N. C. Gen. Stat. 1943, § 1-97; S. C. CODE 1942, \$ 7797; PURDON'S PA. STAT. ANN. 1953, Tit. $12 \$ 297$; WILlianrs' Tenn. Code 1934, 8669; Vernon's Tex. Crv. Stat. 1950, \$2033 (b); VT. STATS. REv. 1947, 1556.

${ }^{23}$ International Shoe Co. v. Washington, 326 U. S. 310, 316 (1945). 
through substituted service in causes of action arising out of these minimum contacts, without forcing the local aggrieved resiclent to go to the expense of suing in the defendant's state. ${ }^{24}$

Although Mr. Justice Stone's above quoted remarks were made in a case involving a foreign corporation it would seem that the rationale of the International Shoe case is also applicable to the nonresident individual or unincorporated business unit.

It seems quite clear, therefore, that the Flexner decision has been in principle overruled.25 That logical consequence of the International Shoe case was expressly recognized in an Arkansas case $^{26}$ and in a recent Tennessee case ${ }^{27}$ upholding substituted service on an out-of-state unincorporated association. And, although the International Shoe case was not mentioned, two subsequent Utah cases ${ }^{28}$ reflect the "substantial justice" approach of that case by reasoning that it is not an unfair imposition upon the nonresident to make him defend in the state where he commits the alleged wrong. A few additional recent cases pay lip service to some of the traditional evasive techniques by resort to the concept of the hazardous undertaking and of regulated business. ${ }^{20}$ In a lone later case, ${ }^{30}$ one court has failed to read the handwriting on the wall left by the International Shoe case and, by dictum at least, purports to follow the doctrine of Flexner v. Frarson, although the case can be explained as one where the nonresident did not come within the "doing business" terminology of the local statute, under the traditional. interpretation of "doing business." 31

24 Application of the rationale to foreign corporations was recently made in Krnach v. Electro-life, 13 F. R. D. 131 (N. D. Ohio 1952); Klein v. Sunbeam Corp., — Dol. -, 94 A. 2d 385 (1952).

${ }_{25}$ Overton, Broadening the Basis of Individual In Personam Jurisatiotion in Tennessee, 22 Teans. L. Rev. 237 (1952) at p. 244. Seo also, Resturearent, Conflict of Laws, $\$ 84$; Restatement, Judaments, $\$ 22$.

${ }^{26}$ Gillioz v. Kincannon, 213 Ark. 1010, 214 S. W. 2 d 212 (1948).

${ }^{27}$ MeDaniel v. Textile Workers Union of America, - Tenn, -, $254 \mathrm{~S}$. W. 2d 1 (1952).

28 Wein v. Grockett, 113 Utah 301, 195 P. 2d 222, 228 (1948) : "to require a resident who is transacting bnsiness in this locality to commence his action in a foreign jurisdiction on a canse of action arising here and transplant his witnesses to other estates would make protection of his right prohibitive." Alward v. Green, - Utah -, 245 P. $2 d 855$ (1952).

${ }^{29}$ Condon v. Snipes, 205 Miss. 306, 326, 38 S. 2d 752, 756 (1949), "wo are not called npon to pass the validity where the defendent is not subject to state regulation." Davis v. Nugent, 90 F. Supp. 52 (D. C. Miss. 1950).

${ }_{30}$ Travis v. Fuqua, 121 Ind. App. 440,97 N. E. $2 d 867$ (1951).

31 Not only was the activity mere solicitation, but it was solicitation by a carrier for transportation which was to take place ontside of the jurisdiction where the ticket was sold. 
Besides the foregoing judicial developments since the International Shoe case, six states ${ }^{32}$ have enacted statutes providing for local suit by substituted service against the nonresident unincorporated business unit, two of them relating only to unincorporated associations. ${ }^{33}$

Under the "minimum contacts" test for satisfying a due process requirement, ${ }^{34}$ the International Shoe case offers a basis for further jurisdictional expansion of the state courts beyond the traditional concept of "doing business." For example, solicitation, even repeated solicitation, of local orders for acceptance out of state, for goods to be shipped from out of state, was traditionally not held to amount to doing business. ${ }^{35}$ But it does not follow that such repeated solicitation does not subject the out-of-state enterprise to local suit if the local statute is so drafted as to take advantage of the Constitutional largesse of the International Shoe case. Several cases involving foreign corporations decided since the International Shoe case are illustrative. In one case the single isolated act of repairing a roof within the jurisdiction was held sufficient contact with the state to make the nonresident corporation amenable to local service of process in action for a tort connected with the act. $^{30}$ In another case the use of an airport by the nonresident corporation's airplane was held to constitute enough contact nnder the minimum contacts test to validate substituted service of process on the corporation. ${ }^{37}$ A frank statutory expansion of local jurisdiction was upheld in a recent Federal decision ${ }^{38}$ under a local

32 ARK. STAT. 1947, $\& 27-340$ : "'by the doing or the performing of such work." Note, 3 ARK. L. REV. 22 (1947) : "the Arkansas general assembly may have been motivated by that decision [International Shoe case] in the enactment of the act." FLA. STAT. ANN. 1951, $\$ 4716$ : "any transaction or transactions or operation with or incidental to business or business venture." MAss. ANN. LAWS 1949 , c. 227 , \$5 (A): "doing business within the state." UTAH CODE ANN. 1947, $\$ 78-27-20$ : "doing business in this state."

${ }^{33}$ ConN. Gen. Stat. 1947, c. 384, $\$ 7776$ : "doing business, acting or carryiug out its operations.", Wriliars' TENN. CoDE \$8681.1, 1952 Supp.

34 The other requiremeuts in regard to service of process are notice and the opportunity to defend. Simon v. Graft, 182 U. S. 427 (1901).

${ }^{36}$ Green v. Chicago, Burlington \& Quiney Ry. Co., 205 U. S. 530 (1907).

${ }^{30}$ Smyth $\nabla$. Twin State Improvement Corp., 116 Vt. 569, 577, 80 A. 2d 664,669 (1951), referring to cases contra to the holding in the case the court said, "They all precede in time the International Shoe decision, which marked a change in the judicial climate." VT. Acrs 1947, \$1562 was the statute upheld.

${ }^{37}$ Peters v. Robin Airlines, - Misc. -, 118 N. Y. S. 2d 238 (1952).

${ }^{38}$ Johns v. Bay State Abrasive Products Co., 89 F. Supp. 654 (D. C. Md. 1950 ). 
statute expressly permitting local suit by substituted service "on any cause of action arising out of a contract made within this state of liability incurred for acts done within this state, whether or not such foreign corporation is doing or has done business in this state."39 [Italies added.] While the court admitted that the acts of solicitation of the defendant would not amount to "doing business," they were sufficient to make him amenable to local suit under the statute. The same doctrines would seem equally applicable, under appropriate statute, to nonresident individuals having such minimum contacts.

Courts have not as yet substantially expanded the "doing business" basis of jurisdiction, being restricted by the wording of the state statute and the gloss which the term has acquired. ${ }^{40}$ However, it was the broad interpretation of the local statute phrased in terms of "doing business" that led to the Supreme Court decision in the International Shoe case. The lone solicitation case ${ }^{41}$ involving a nonresident individual to arise subsequent to the decision in the International Shoe case suggests that the nonresident was not engaged in business within the state by merely soliciting contracts of entertainment at schools; although another explanation is that the person served was not sufficiently an "agent."

It remains for the legislatures of the states to take advantage of their expanded constitutional power to determine what acts will subject the defendant to local suit. A statute has been suggested eliminating the ambiguous term, "doing business," and which would permit local suit: "For any and all actions, suits, demands,

30 FuACK's MD. ANN. STAT. 1947, a. $23 \$ 119$ (d).

${ }^{10}$ Charles Keeshin, Ine. v. Gordon Johnson Co., 109 F. Supp. 939 (W. D. Ark. 1952); Melvin Pine \& Co. v. MeConnell, 273 App. Div. 218, 76 N. Y. S. $2 d 279$ (1948), aff' $d 298$ N. Y. 27, 30, 80 N. E. $2 d$ 137, 137 (1948): "It is unnecessary at this time to say, whether and to what extent that test may bo relaxed in reliance upou the constitutional principles receutly aunounced by the Supreme Court in International Shoe Co. v. Washington." For case prior to the International Shoe case holding that solicitation per se is not doing business within the forum see: O'Hagau v. Caballero, 52 N. Y. S. 2d 863, aff' $d$ without opinion 269 App. Div. 981, 59 N. Y. S. 2 d 300 (1945); Debroy v. Hanna, 182 Mise. 824, 45 N. Y. S. 2d 551 (1943) ; Johnson Freight Lines v. Davis, 170 Tenn. 177, 93 S. W. $2 d 637$ (1936); Kaffenberger v. Kremer $63 \mathrm{~F}$. Supp. 924 (E. D. Pa. 1945) ; Deutsch v. Hoge, 146 F. 2d 201, 203 (2d Cir. 1944): L. Hand in dissent, “. . . when an individual sends agents into the state . . . continuously to solicitate orders, he subjects himself to sorvice by notice alone ..." C $f$. Storey v. United Ins. Co., 64 F. Supp. 896 (E. D. S. O. 1946).

${ }^{11}$ Alward v. Green, - Utah -, 245 P. $2 d 855$ (1952). 
or claims in law or equity, either at common law, or under appropriate statute arising out of the commission of the tort, or making or breach of the contracted obligation." 42

In conclusion, the International Shoe case affords a basis for the expansion of local suits against the nonresident individuals in three dircctions :

(1) It impliedly overrules Flexner v. Frarson.

(2) It offers a basis for upholding a state statute defining the acts of the nonresident not as the traditional "doing business," but more broadly, as categories amounting to "minimum contacts" with the local state.

(3) It may lead the court, without help from the legislature, to modify their doing business requirement so as to include those acts amounting to "minimum contacts" with the forum.

42 Overton, Broadening In Personam. Jurisdiction in Tennessee, 22 TENN. L. REv. 238 (1952), at p. 248 . The statute was only to apply to the individual nonresident. 